\title{
Afforestation/reforestation of New Zealand marginal pasture lands by indigenous shrublands: the potential for Kyoto forest sinks
}

\author{
Craig Trotter ${ }^{\mathrm{a} *}$, Kevin TAte ${ }^{\mathrm{a}}$, Neal ScOtT ${ }^{\mathrm{b}}, \mathrm{Jacqueline} \mathrm{TOWNSEND}^{\mathrm{a}}$, Hugh WILDE ${ }^{\mathrm{a}}$, Suzanne LAMBIE ${ }^{\mathrm{a}}$, \\ Mike MARDEN $^{\mathrm{a}}$, Ted PINKNEY ${ }^{\mathrm{a}}$ \\ a Landcare Research, Private Bag 11052, Palmerston North, New Zealand \\ b Woods Hole Research Center, P O Box 296, Woods Hole, MA, USA
}

(Received 13 April 2004; accepted 7 April 2005)

\begin{abstract}
New Zealand will use the afforestation/reforestation (A/R) provisions of article 3.3 of the Kyoto protocol to help offset greenhouse gas emissions during the first commitment period, 2008 to 2012. We assess here the potential initial C sink available from A/R of marginal pasture lands by New Zealand's most common shrubland species: mānuka (Leptospermum scoparium) and kānuka (Kunzea ericoides). Plotbased mensuration shows that mean net $\mathrm{C}$ accumulation rates for mānuka/kānuka shrubland are in the range 1.9 to $2.5 \mathrm{t} \mathrm{C}^{-1} \mathrm{yr}^{-1}$, when averaged over the active growth phase of about 40 years. Estimates of the change in mineral soil $\mathrm{C}$ with shrubland $\mathrm{A} / \mathrm{R}$ of grassland suggest small losses occur, although these appear to be largely offset by accumulation of $\mathrm{C}$ in the litter layers. Analysis shows that nationally there are about 1.45 Mha of marginal pastoral land suitable for $\mathrm{A} / \mathrm{R}$ by indigenous shrubland or forest. This area could accumulate about $2.9 \pm 0.5 \mathrm{Mt} \mathrm{C} \mathrm{yr}^{-1}$, a significant offset to New Zealand's annual energy-related $\mathrm{CO}_{2}$ emissions of $8.81 \mathrm{Mt} \mathrm{CO}_{2}-\mathrm{C} \mathrm{yr}^{-1}$. An initial economic analysis of livestock farming for a region with large areas of land marginal for sustained pastoral agriculture suggests "carbon farming" may prove an attractive alternative land use if international prices for biomass-C reach about $€ 10$ per tonne $\mathrm{CO}_{2}$.
\end{abstract}

afforestation / reforestation / Kyoto protocol / carbon sink / shrubland

Résumé - Boisement/reboisement des pâturages marginaux de Nouvelle-Zélande par des formations arbustives indigènes : potentiel pour les puits de carbone du protocole de Kyoto. La Nouvelle-Zélande va utiliser les provisions de boisement/reboisement (A/R) de l'article 3.3 du protocole de Kyoto pour compenser les émissions de gaz à effets de serre, pendant la première période d'engagement 2008-2012. Nous évaluons ici le potentiel initial de puits de $\mathrm{C}$ rendus disponible par l'A/R des pâturages marginaux par les espèces arbustives les plus communes de Nouvelle-Zélande : le mānuka (Leptospermum scoparium) et le kānuka (Kunzea ericiodes). Les mesures réalisées sur des parcelles d'étude de comparaison par paire montrent que la moyenne du taux net d'accumulation de carbone pour le mānuka/kānuka, sur une période d'environ 40 ans de la phase de croissance active, est de l'ordre de 1,9 à $2,5 \mathrm{t} \mathrm{C} \mathrm{ha}^{-1}$ par an. Des études sur les changements en $\mathrm{C}$ minéral du sol sur une $\mathrm{A} / \mathrm{R}$ arbustive de prairies suggèrent des pertes mineures, qui seraient apparemment largement compensées par une accumulation dans la litière et dans la couche d'humus. Des études sur les changements en $C$ minéral du sol sur une A/R arbustive de prairies suggèrent des pertes mineures, qui seraient apparemment largement compensées par une accumulation dans la litière. Des analyses montrent qu'au niveau national environ 1,45 Mha de pâturages marginaux seraient appropriés pour une $\mathrm{A} / \mathrm{R}$ par arbuste ou forêt indigène. Ces zones pourraient accumuler environ $2.9 \pm 0.5 \mathrm{Mt}$ de $\mathrm{C}$ par an, une compensation significative aux émissions annuelles de combustible fossile en $\mathrm{CO}_{2}$ de la Nouvelle-Zélande, estimées à 8,84 Mt de $\mathrm{C}-\mathrm{CO}_{2}$ par an. Des analyses économiques préliminaires d'activité d'élevage sur une région dont les prairies comprennent d'importantes zones marginales pour une agriculture pastorale durable suggèrent que la « culture de carbone » pourrait s'avérer une alternative intéressante d'utilisation du sol, si les prix internationaux de carbone de biomasse atteignent environ $10 €$ par tonne de $\mathrm{CO}_{2}$.

boisement / reboisement / protocole de Kyoto / puits de carbone / formations arbustives

\section{INTRODUCTION}

As a signatory to the United Nations Framework Convention for Climate Change, New Zealand (NZ) is committed to developing both a national system of carbon (C) inventory, and policy to reduce net greenhouse gas emissions [29, 33]. These developments have gained considerable impetus recently with
NZ's ratification of the Kyoto protocol. Under the Protocol, a demonstrable reduction of about $85 \mathrm{Mt}$ of $\mathrm{CO}_{2}$ equivalent will be required to meet NZ's assigned amount of emissions during the first commitment period, 2008-2012 [30, 34]. As with many countries, energy efficiency and conservation initiatives - together with development of renewable energy technologies - will form a major part of longer-term strategy to reduce

\footnotetext{
* Corresponding author: trotterc@landcareresearch.co.nz
} 
Table I. Characteristics and net carbon accumulation rates for mānuka/kānuka shrubland sites. Values are means, with standard deviations indicated for $\mathrm{C}$ accumulation rates.

\begin{tabular}{|c|c|c|c|c|c|}
\hline Site & $\begin{array}{c}\text { Accumulation } \\
\text { rate* } \\
\left(\mathrm{t} \mathrm{C} \mathrm{ha}^{-1}\right)\end{array}$ & $\begin{array}{c}\text { Rainfall* } \\
(\mathrm{mm})\end{array}$ & $\begin{array}{l}\text { Water } \\
\text { deficit* } \\
(\mathrm{mm})\end{array}$ & $\begin{array}{l}\text { Temp.* } \\
\left({ }^{\circ} \mathrm{C}\right)\end{array}$ & $\begin{array}{l}\text { Foliar } \\
\mathrm{N} \\
(\%)\end{array}$ \\
\hline Turangi: cool, lower fertility & $1.9 \pm 0.3$ & 2500 & 0 & 9.3 & 1.33 \\
\hline Dunedin: cool, higher fertility & $2.5 \pm 0.2$ & 1030 & 8 & 9.2 & 1.62 \\
\hline Waitakere: warm, lower fertility & $2.1 \pm 0.6$ & 1800 & 10 & 13.6 & 1.33 \\
\hline Gisborne: warm, lower fertility & $1.8 \pm 0.3$ & 1400 & 60 & 14.2 & 1.37 \\
\hline Gisborne: warm, higher fertility & $2.2 \pm 0.3$ & 1520 & 37 & 13.7 & 1.69 \\
\hline
\end{tabular}

* Mean annual data.

emissions. However, in the short- to medium-term, NZ proposes to meet about half its emissions target by exercising the afforestation and reforestation $(\mathrm{A} / \mathrm{R})$ offset provisions of article 3.3 of the Kyoto protocol [33, 48].

Accumulation of $\mathrm{C}$ in exotic plantation forests established on former grassland since 1990 - Kyoto forests - will provide the major $\mathrm{A} / \mathrm{R}$ offsets for $\mathrm{NZ}$ [42, 43, 45]. However, an important additional $C$ sink could be created through $A / R$ by indigenous shrublands of steep erosion-prone pastorallyfarmed hill country, that environmentally is marginal for longterm agriculture [40, 42, 45]. The most common colonising shrubland species are mānuka (Leptospermum scoparium J. R. Forst. \& G. Forst.) and kānuka (Kunzea ericoides var. ericoides (A. Rich) J. Thompson). These species can achieve relatively high levels of $\mathrm{C}$ storage for shrubland - up to $140 \mathrm{t} \mathrm{C} \mathrm{ha}^{-1}$ at favourable sites, in stands with stems of more than $25 \mathrm{~cm}$ diameter and $15 \mathrm{~m}$ height $[40,45]$. Furthermore, reversion of marginal pastoral hill-country to mānuka/kānuka shrubland meets a range of additional objectives in sustainable environmental management: creation of indigenous biodiversity, erosion mitigation and soil conservation, consequent improvements in water quality, and creation of environmentally benign revenue from honey, nutriceutical, and pharmaceutical industries [45]. Importantly, from a $\mathrm{C}$ sink perspective, in many areas indigenous shrubland provides the first step in a successional pathway to a permanent cover of indigenous tall forest (e.g., [1, 14, 32, 49]). Because of NZ's temperate climate, fire seldom interferes with this succession. The resultant forests typically comprise long-lived species that can achieve large stature, with diameters of 1-2 $\mathrm{m}$ and an active growth phase that extends from 150 to 500 years (e.g., [13-15, 18]). Active net C accumulation over such time frames is consistent with the prolonged effort likely required to effect significant reductions in atmospheric $\mathrm{CO}_{2}$ levels $[17,38]$.

Mānuka/kānuka shrublands have only recently become recognised in NZ as a potentially important C sink [40, 42, 45], and as such relatively little is yet known about $\mathrm{C}$ sequestration in these species. In this paper we summarise the results of recent research to characterise above- and below-ground biomass accumulation in these shrublands, and to determine the effect on soil $\mathrm{C}$ of shrubland $\mathrm{A} / \mathrm{R}$ of pasture lands. Also included is an initial evaluation of the potential national $\mathrm{C}$ gain from establishing indigenous shrublands on all lands marginal for pastoral agriculture: a change from agricultural land use to "carbon farming". We conclude with a simple analysis to assess the approximate economic returns from carbon farming on erodible pastoral hill country, in comparison with returns from more traditional livestock farming on such lands.

\section{METHODS}

\subsection{Estimation of mānuka/kānuka biomass}

Although termed shrub species, mānuka and kānuka in other than the juvenile phase develop a defined stem and crown structure that is similar to small forest trees. Allometric equations relating above- and below-ground (coarse root) biomass to diameter at breast height (DBH) can therefore be developed [40]. Details of sampling and analysis protocols for determining allometric equations for mānuka and kānuka have been reported elsewhere [40], where it has been shown that there is no significant difference between equations for these two shrubland species. For this study equations were derived by destructive harvest of mānuka/kānuka at five sites broadly spanning the range of climo-edaphic conditions under which these species readily establish (e.g. [49]). Site information is given in Table I, and locations are indicated in Figure 1. The allometric equation developed for live above-ground biomass (AGB) was based on analysis of 150 trees with stem diameters ranging from 1 to $36 \mathrm{~cm}$. Coarse root biomass was determined for a subsample of 40 of these trees, and used to generate the alometric equation for live below-ground biomass.

Plots to determine biomass were established within relatively mature stands of about 40 years age at each of the sites. A previous chronosequence study at the Turangi site had suggested stands of this age are close to maturity [40], although C accumulation may continue for longer at the most favourable sites (C.M. Trotter, unpublished data). Stand age was determined by ring-counting of basal slices from a sample of trees, or from local knowledge of land-use history and stand establishment. Variable-area plots were used for all measurements [3, 40], as stem spacing varied widely with site conditions. Most plots included at least 25 stems, with five plots per stand whenever practical. Because of the irregular shape of many stands, plots were often unable to be located along a single straight-line transect. If this occurred, transect shapes were arranged to ensure all plots were well inside the stand boundary, with plots spaced at fixed intervals along rectangular, L-shaped, or fixed-angle zig-zag transects. Measurements of DBH were made on all live stems in each plot, and converted to biomass using the allometric equations. Mean net biomass accumulation rates were calculated as the sum of live ABG and coarse root biomass, divided by stand age. Carbon in the litter and humus layers was estimated at a subset of the plots following the methodology given in Coomes et al. [7], using $0.1 \mathrm{~m}^{2}$ quadrat samples. 


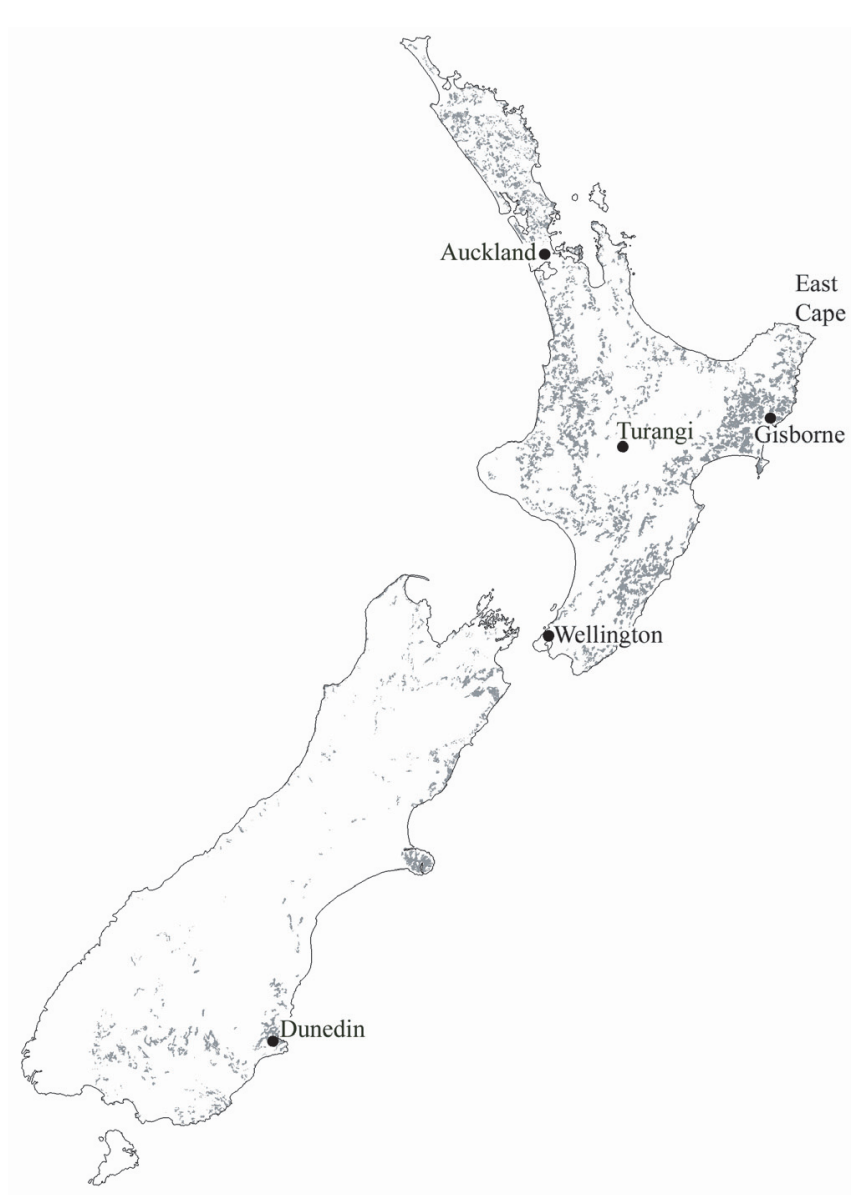

Figure 1. Potential area for afforestation/reforestation of marginal pasture lands by indigenous shrublands and forests. Study site locations are also indicated.

\subsection{Effect of shrubland on soil carbon}

Mean differences in steady-state mineral soil C resulting from landuse/landcover change can be obtained from the NZ carbon monitoring system (CMS). This is a NZ-specific, Tier-2 extension of the Intergovernmental Panel on Climate Change (IPCC) default methodology for soil $\mathrm{C}$ inventory, in which NZ is stratified by the following parameters: soil class, climate, land cover, and topography [19, 41, 43]. Generalised linear modelling (GLM) was used to derive estimates of steady-state mineral soil $\mathrm{C}$ in terms of these parameters, from over 3000 soil $\mathrm{C}$ samples in a georeferenced national soil pedon dataset [43]. Any samples that might have come from sites associated with recent land use change were excluded.

The best predictor was an additive model of (in order of significance): soil class - climate + land cover + slope $\times$ precipitation $[43$, 44]. The slope times precipitation factor is a measure of the long-term propensity of a site to erode, and was a better predictor of mineral soil $\mathrm{C}$ than other topo-climatic variables [43]. The GLM model was used to estimate mean national mineral soil $\mathrm{C}$ stocks for pasture land and for indigenous shrubland undifferentiated by species, with standard errors of the mean (SE) derived directly from the GLM analysis. The present analysis is based on more than 1500 pasture sites, and 130 shrubland sites. A full description of the design, development and testing of the $\mathrm{NZ}$ soil CMS is given elsewhere [41, 43].

\subsection{Estimation of shrubland potential area and economic value}

Establishing the potential area of indigenous shrubland that may occur by natural regeneration on pasture lands requires first locating areas in which shrubland seed sources are available. The likely presence of seed sources was determined from the Vegetative Cover Map (VCM, [32]) of NZ. This map includes two vegetation classes of primary relevance to indigenous shrubland reversion: grassland with scattered mānuka/kānuka, and grassland with scattered mixed-species hardwood shrubland. However, the VCM was compiled at 1:250 000 scale, and as such includes small unresolved areas of closed-canopy shrublands. To exclude such areas, use was made of a more recent landcover map compiled from 1996 satellite imagery with a spatial resolution of $20 \mathrm{~m}$ : the NZ Landcover Database (LCDB, [24]). The LCDB map distinguishes only a limited number of thematic classes, but is sufficient to define areas that are primarily pasture, at a nominal spatial resolution of 1 ha [24]. The "primarily pasture" description is used because such lands may include a minor scattered shrub component insufficient to significantly affect the spectral signature of the satellite imagery. Intersection of the VCM and LCDB thus identifies areas of pasture for which indigenous shrubland seed sources can be expected to be either present, or locally adjacent. In an analogous manner to that for shrubland, intersection of the VCM and LCDB was also used to identify areas of pasture land that either contain, or have adjacent, indigenous forest seed sources, representing areas likely to regenerate directly to tall forest without first passing through a successional shrubland phase.

The resultant VCM/LCDB intersected area represents pasture land that will frequently also include minor scattered indigenous shrubland or forest remnants. We assume, for the purposes of this study, that all such land is eligible for the creation of Kyoto forest (for further discussion, see Sect. 3.3). The VCM/LCDB intersected area was then further intersected with data from the NZ Land Resource Inventory (NZLRI), to define those areas where shrubland and forest seed sources were likely to occur on land marginal for continued pastoral farming. The NZLRI describes the lithological, soil, land cover and physical characteristics of land resources of $\mathrm{NZ}$ at 1:50 000 scale, and couples these factors with climate to derive indices ranking land for land-use suitability, sustainable production, rates of primary production, and erosion risk $[11,21]$. Hill country areas with an erosion risk rating of medium to extreme under a pastoral farming regime - risk classes 3 to 6 - constitute marginal lands on the basis of long-term productive sustainability $[11,21,28,35,46,47]$.

The economic analysis presented here is intended only as a firstorder estimate of the revenue likely from shrubland $\mathrm{C}$ storage in comparison with livestock farming, and is derived on an annual gross margin basis. Mean annual gross margins for livestock farming were supplied by the Ministry of Agriculture and Forestry's Farm Monitoring Unit, and are based on a detailed analysis of farm financial and livestock records [27]. Calculating gross margins for shrubland $A / R$ is much more approximate. Estimates were made by assuming closed-canopy stands, with revenue equal to a mean annual shrubland $\mathrm{C}$ accumulation rate times a given $\mathrm{C}$ price. In nominating the particular mean $\mathrm{C}$ accumulation rate we account only very simply for $\mathrm{C}$ sequestration under indigenous $\mathrm{A} / \mathrm{R}$ of pasture lands being a discontinuous process. That is, at maturity, shrubland stands become largely $\mathrm{C}$ neutral, and so revenue from $\mathrm{C}$ accumulation ceases. No further revenue occurs until $\mathrm{C}$ stocks again begin to increase well into the successional phase to tall indigenous forest, a process that may take some decades. In an attempt to account at least in part for such discontinuous $\mathrm{C}$ accumulation, we base annual revenue on an effective long-term mean $\mathrm{C}$ accumulation rate calculated by assuming $\mathrm{C}$ stocks present at shrubland maturity actually develop over the considerably longer period required for indigenous forest species to become dominant. Quantitative studies on the long-term temporal dynamics of succession in NZ shrublands have 
yet to be reported, but simple observation of structure in old, mixed shrubland/forest stands suggests $\mathrm{C}$ stocks are likely to start increasing again about 100 years after initial shrubland establishment. More sophisticated approaches to economic valuation than used here may be warranted in the future. However, the long time intervals and consequent uncertainty involved in both $\mathrm{A} / \mathrm{R}$ schemes and succession to indigenous forest, and the uncertainty of future $\mathrm{C}$ prices and international policy, will always considerably complicate such analyses.

\section{RESULTS AND DISCUSSION}

\subsection{Carbon accumulation in mānuka/kānuka shrubland}

Destructive harvest of mānuka/kānuka to determine ABG and coarse root biomass yielded strong linear relationships between log-log transformations of DBH and AGB, or DBH and coarse root biomass: adjusted $r^{2}$ values of 0.98 or 0.92 , respectively. Site location had no significant effect on the slope $(P=0.11)$, and a significant $(P<0.0001)$ but minor effect on the intercept, of the log-log equations. Equations derived by fitting to data from all sites gave a mean difference between predicted and measured biomass that was smaller than the standard deviation (SD) of the mean error of prediction obtained using site-dependent equations. That is, the mean differences between sites were smaller than those arising from variation between trees at an individual site. Mānuka/kānuka biomass can therefore be estimated without loss of accuracy over a wide range of climo-edaphic conditions using a single set of allometric equations.

Mean rates of net live biomass-C accumulation in mānuka/ kānuka stands close to 40 years of age, for five sites with varying climate and soil fertility, are given in Table I. Variation in the mean accumulation rates broadly reflects trends in nutrient and water availability (water deficit). Temperature appears to have little effect on growth rates: compare, for example, the net mean $\mathrm{C}$ accumulation rate at the Turangi and Auckland, or Dunedin and the higher fertility Gisborne, sites (Tab. I). This is consistent with increasing evidence that the optimum temperature for photosynthesis in especially widely distributed species undergoes considerable seasonal acclimation $[4,6,12]$ - although constraints ultimately remain on growth rates at very low temperatures because of physical damage and prolonged stomatal closure caused by frost.

The mean $( \pm$ SD) net $C$ accumulation rate for total live biomass in mānuka/kānuka stands across all sites was $2.1 \pm 0.2 \mathrm{t} \mathrm{C}$ $\mathrm{ha}^{-1} \mathrm{y}^{-1}$. This is somewhat larger than the average of $1.1 \mathrm{tC}$ $\mathrm{ha}^{-1} \mathrm{y}^{-1}$ obtained from verified modelling over the 350 years to maturity of NZ conifer-dominated indigenous forest at a relatively dry, warm site of moderate fertility [13]; and also more than the average of $1.5 \mathrm{t} \mathrm{C} \mathrm{ha}^{-1} \mathrm{y}^{-1}$ measured for a mature 150 year old stand of NZ beech forest in a wet, cold environment with poorer fertility $[2,9]$. As expected, however, the rate is considerably smaller than the national mean rate of $\mathrm{C}$ accumulation of about $8 \mathrm{tC} \mathrm{ha}^{-1} \mathrm{y}^{-1}$ achieved over a typical rotation cycle in exotic plantation forests $[25,26]$.

The differences in rates of net $\mathrm{C}$ accumulation between exotic plantation forests and those for indigenous shrublands and forests are not, however, the result of large differences in net primary production [45]. Rather, they occur because the indigenous species establish naturally at very high stem densities (e.g., $[15,40]$ ), with much biomass subsequently lost during self-thinning. For example, at the low fertility Turangi site, NPP has been estimated at $15 \mathrm{t} \mathrm{Cha}^{-1} \mathrm{y}^{-1}$, using a coupled photosynthesis-stomatal conductance model $[22,23]$ that incorporates leaf respiration, and site energy and water balances [50]. Even allowing for the relatively large rates of foliage and fine root turnover in mānuka/kānuka [45, 50], the relatively high value of NPP suggests considerably better rates of net $\mathrm{C}$ accumulation in total live biomass could be achieved if self-mortality was reduced. Thinning of juvenile stands to reduce stem densities to levels that would prevent stem mortality over the active growth phase may be a cost-effective option. The losses in $\mathrm{C}$ from decay of thinnings from such stands would only be a small fraction of the total additional net $\mathrm{C}$ gain achieved by preventing self-mortality over the stand lifetime.

\subsection{Change in soil carbon with reversion of grasslands to shrubland}

Whether mineral soil $\mathrm{C}$ increases, decreases, or remains unchanged with changes in land use depends on the particular soil class, climate, and land-cover/use change involved (e.g., [36]). However, as a general rule, changes in land cover from pasture land to woody vegetation can be expected to result in a gradual decline in mineral soil C, possibly for several decades, until a new steady-state is reached $[20,36,39,43]$. The difference in mean national mineral soil $\mathrm{C}$ stocks under steady-state conditions for NZ pasture land and shrubland sites in the national pedon dataset, estimated using the methodology outlined in Section 2.2, confirms that a small mean $( \pm \mathrm{SE})$ longterm loss of $14 \pm 5 \mathrm{t} \mathrm{Cha}^{-1}$ to $30 \mathrm{~cm}$ depth is likely for shrubland $\mathrm{A} / \mathrm{R}$ of pasture land $[42,44]$.

As found also in forest studies in NZ [8, 39, 43], the small losses in mineral soil $\mathrm{C}$ that occur with $\mathrm{A} / \mathrm{R}$ of pasture land appear to be largely offset by long-term $\mathrm{C}$ gains in forest or shrubland litter and humus layers. For the shrubland sites in this study, the accumulated litter/humus $\mathrm{C}$ averaged $( \pm \mathrm{SE})$ $11.5 \pm 0.5 \mathrm{tha}^{-1}(n=35)$. This value is consistent with other independent NZ studies. For 29 sites in a transect across South Island, litter/humus C averaged ( \pm SE) $14.1 \pm 4.3 \mathrm{t} \mathrm{Cha}^{-1}[7]$, although the sites included indigenous shrubland species other than just mānuka/kānuka. Mean values of $\mathrm{C}$ in the litter/humus layers of mature indigenous forest are very similar $[8,16$,$] .$ Overall, it appears that little net change in $\mathrm{C}$ is likely for the combined mineral soil and litter/humus pools with $\mathrm{A} / \mathrm{R}$ of pasture land by either indigenous shrubland or forest.

\subsection{Potential shrubland area and carbon accumulation}

Figure 1 shows the distribution of marginal pasture lands likely to contain sufficient seed sources to induce A/R by natural regeneration of indigenous shrubland or forest species. Although natural regeneration is involved, the process is deemed Kyoto-compliant because significant increases in establishment and canopy cover occur only in response to human action: the removal of livestock, and cessation of the normal agricultural practice of periodic clearance of scattered shrubland that continually re-colonises grassland. Indeed, most of the scattered 
vegetation presently available to act as seed sources exists because it has been deliberately retained on and confined to the least productive, most highly erodible land - through successive cycles of livestock removal, reversion, and re-clearance that occur in response to long-term variations in agricultural commodity prices.

Analysis of the VCM/LCDB/NZLRI spatial datasets shows that the area of marginal pastoral land likely to revert to mānuka/kānuka shrubland following livestock removal is $0.88 \mathrm{Mha}$. A further $0.36 \mathrm{Mha}$ is suitable for reversion to mixed indigenous shrubland, typically comprising a large component of mānuka/kānuka interspersed with fast-growing indigenous broadleaved hardwoods. Also, there are 0.21 Mha of marginal pasture land that because of local seed source availability are most likely to revert directly to indigenous tree species without passing through a successional shrubland phase. More than $90 \%$ of the potential area for shrubland A/R is in North Island, with a large proportion of that area confined to the Tertiary softrock, erodible hill country along the east coast. Potentially, then, there is a total of about 1.45 Mha of marginal pasture lands available for A/R by indigenous shrubland and forest.

To make an initial estimate of the national potential $\mathrm{C}$ accumulation on these marginal lands we assume recently established indigenous broadleaved shrubland achieves similar rates of $\mathrm{C}$ accumulation to mānuka/kānuka, with indigenous forest achieving about two-thirds those rates (see Sect. 3.1). If the $\mathrm{C}$ accumulation rates in Table I are weighted broadly according to the distribution of climate and soil nutrient conditions throughout the potential shrubland/forest area shown in Figure 1, an annual national net $\mathrm{C}$ accumulation of about $2.9 \pm 0.5 \mathrm{Mt}$ is likely to be achieved on available marginal lands, once stands are well established. The error given here has been estimated by repeating the calculation assuming the mean values in Table I are reduced to the lower and upper limits, respectively, of the SDs. If carbon accumulation rates of this magnitude were to be achieved, a substantial contribution would be made to offsetting NZ's annual C emissions from fossil fuel use and cement production of $8.84 \mathrm{Mt} \mathrm{CO}_{2}-\mathrm{C}$ [31].

\subsection{Estimating the economic value of "carbon farming"}

An initial estimate of economic returns was made for mānuka/kānuka shrubland A/R schemes that might be established in the upper east coast region (Gisborne to East Cape Fig. 1) of the North Island. This region was chosen primarily because the mean rates of $\mathrm{C}$ accumulation reported for the Gisborne sites (Tab. I) are based on a larger number of stands (20) spread over a wider range of localities than for other sites, and are thus considered more regionally representative. Studies have concentrated on this region because it would benefit substantially from A/R schemes, as the regional geology strongly predisposes steep pastoral hill country in this area to high rates of erosion (e.g., [5, 10, 28, 46]). Well-established mānuka/ kānuka stands are almost as effective as exotic plantation forest in preventing shallow landslides on this hill country, and reduce erosion rates by about $90 \%[5,10]$. As discussed in Section 2.3, for the purposes of economic estimates the long-term rates of $\mathrm{C}$ accumulation in Table I are further reduced as an approximate way of accounting for the lack of revenue flow in shrub- land $\mathrm{A} / \mathrm{R}$ schemes between the period from stand maturity and succession to tall indigenous forest. Mānuka/kānuka stands in the Gisborne region appear to accumulate $\mathrm{C}$ up to about 60 years of age (C M Trotter, unpublished data), with rates in Table I therefore suggesting an equivalent long-term, 100-year mean $\mathrm{C}$ accumulation rate for the Gisborne sites of about $1.2 \mathrm{t} \mathrm{C}$ $\mathrm{ha}^{-1} \mathrm{y}^{-1}$.

Revenue from livestock farming on typical hill country in the Gisborne/East Cape region varies strongly with international commodity prices. Gross margins for hill country farms in the region averaged about $€ 14$ per stock unit (SU) after stock revaluations in the buoyant 2000/2001 season [27]. However, over a longer 10-year period more consistent with commitment to $\mathrm{A} / \mathrm{R}$ schemes, inflation-adjusted returns (at 2002) were $€ 8.50 / \mathrm{SU}$, with mean carrying capacity averaging $7.8 \mathrm{SU} \mathrm{ha}^{-1}$ [27]. This carrying capacity is very similar to the figure of 7.6 SU ha ${ }^{-1}$ obtained from independent data in the NZLRI database $[11,21]$, for a $1 \mathrm{~km}$ radius around the Gisborne sites. The similarity of SU values for land around the mānuka/kānuka sites, and the mean from the wider geographic spread of farms for which the agricultural statistics are generated, gives confidence that the shrubland sites are on land representative of hill country in the wider region.

Average stock-carrying capacity on the 30000 ha of most highly erosion-prone pasture-land in the upper east coast region is only about $3 \mathrm{SU} \mathrm{ha}{ }^{-1}$, equivalent to an annual gross margin revenue of $€ 25.5 \mathrm{ha}^{-1}$. This suggests that for these lands farmers may consider switching land use from livestock farming, to $\mathrm{C}$ farming based on indigenous shrubland, when $\mathrm{C}$ prices reach about $€ 6 \mathrm{t}^{-1} \mathrm{CO}_{2}$. At prices of about $€ 10 \mathrm{t}^{-1} \mathrm{CO}_{2}$, shrubland $\mathrm{A} / \mathrm{R}$ schemes should provide an economic return similar to or better than livestock farming on about 120000 ha in the region. $\mathrm{NZ}$ has indicated it will place a cap of about $€ 12.5 \mathrm{t}^{-1} \mathrm{CO}_{2}$ on the national tradable price of $\mathrm{C}$ during the first commitment period, 2008-2012, to limit possible economic damage to emitting industries. Should $\mathrm{C}$ prices achieve this capped limit, wellestablished stands of mānuka/kānuka would provide about $75 \%$ of the 10-year average annual gross margin return from livestock farming across all marginal lands in the region.

As presently calculated, the economic returns from shrubland $\mathrm{A} / \mathrm{R}$ do not incorporate either direct or indirect co-benefits. Direct co-benefits include erosion mitigation and soil conservation, a more sustainable land use, improved environmental quality of waterways, a pathway to increasing indigenous biodiversity, and opportunities for expansion of local enterprises based on honey and plant-oil extracts. Indirect co-benefits include reductions in trace gas emissions arising from reductions in stock numbers and fertiliser application, reduced expenditure on farm maintenance, and reductions in both on- and offfarm energy use. However, additional costs are also presently excluded from this initial economic analysis, with possible significant expenditure on fencing, and on control of weeds or animal pests (e.g., possums, that spread bovine tuberculosis; [37]) that may establish in wooded land. Further, although the $\mathrm{C}$ accumulation rates used in the present economic assessment are long-term means, even lower accumulation rates may occur initially on a unit area basis until canopy closure over the entire area occurs. 


\section{CONCLUSIONS}

About 1.45 Mha of NZ hill country that is environmentally and economically marginal for sustained pastoral agriculture has potential to revert to indigenous shrublands or forest, following removal of livestock. The principal colonising shrubland species are mānuka and kānuka, that depending on site conditions could be expected to achieve average $\mathrm{C}$ accumulation rates in the range $1.9-2.5 \mathrm{t} \mathrm{C} \mathrm{ha}^{-1} \mathrm{y}^{-1}$ over the period of active stand growth of about 40 years. If all marginal pasture land available nationally were allowed to revert to indigenous shrubland or forest, an annual $\mathrm{C}$ accumulation of about $2.9 \pm 0.5 \mathrm{Mt}$ would be achieved, providing a substantial offset for NZ's annual C emissions from fossil fuel use and cement production of $8.84 \mathrm{MtCO}_{2}-\mathrm{C}$. Although small losses of mineral soil $\mathrm{C}$ could be expected with such $\mathrm{A} / \mathrm{R}$ of marginal pasture land, current evidence suggests these are likely to be largely offset by long-term accumulation of $\mathrm{C}$ in the litter and humus layers.

An initial analysis of the economics of creating Kyoto-eligible forest sinks, based on shrubland $\mathrm{A} / \mathrm{R}$ of marginal pasture lands, suggests "carbon farming" may represent a viable land use option in the future. At prices of about $€ 10 \mathrm{t}^{-1} \mathrm{CO}_{2}$, shrubland A/R schemes may provide a similar or better economic return to livestock farming on about 120000 ha in the region. The economics of carbon farming are sensitive to the time for succession of shrubland to indigenous tall forest, and also to the time taken for establishing shrubland to achieve full canopy cover. Research is urgently required to develop low-cost methods to accelerate the establishment of both mānuka/kānuka shrubland and the second-phase tall forest. The potential net $\mathrm{C}$ gains from limited silvicultural practice - particularly early thinning of juvenile stands - also need to be investigated. Improvements to the economics of carbon farming would increase the viability of initiatives already under way in NZ to expand forest sinks: the Emissions-Biodiversity Exchange scheme (http://www.ebex21. co.nz), and the Permanent Forest Sinks project (http://www.maf.govt.nz).

Acknowledgements: Mr Duane Redwood, Ministry of Agriculture and Forestry (Farm Monitoring Unit), is thanked for supplying the time-series economic data for the Gisborne Large Hillcountry farm category. Thanks are also due to Anne Sutherland and Hamish Heke for completing the GIS analysis.

\section{REFERENCES}

[1] Allen R.B., Partridge T.R., Lee W.G., Efford M., Ecology of Kunzea ericoides (A. Rich.) J. Thompson (kānuka) in east Otago, New Zealand, N.Z. J. Bot. 30 (1992) 135-149.

[2] Allen R.B., Clinton P.W., Davis M.R., Cation storage and availability along a Nothofagus forest development sequence in New Zealand, Can. J. For. Res. 27 (2002) 323-330.

[3] Batchelor C.L., Craib D.G., A variable area plot method for assessment of forest condition and trend, N.Z. J. Ecol. 8 (1985) 83-96.

[4] Benecke U., Nordmeyer A.H., Carbon uptake and allocation by Nothofagus solandri var. cliffortioides (Hook. f.) Poole and Pinus contorta Douglas ex Loudon ssp. contorta at montane and subalpine altitudes, in: Waring R.H. (Ed.), Carbon Uptake and Allocation in Subalpine Ecosystems as a Key to Management. Forest Ecosystems, Institute of Terrestrial Ecology, Merlewood, UK, 1982, pp. 131-140.
[5] Bergin D.O., Kimberley M.O., Marden M., Protective value of tea tree stands on erosion-prone hill country, East Coast, North Island, New Zealand, N.Z. J. For. Sci. 25 (1995) 3-19.

[6] Berry J., Björkman O., Photosynthetic response and adaptation to temperature in higher plants, Ann. Rev. Plant Physiol. 31 (1980) 491-543.

[7] Coomes D.A., Allen R.B., Scott N.A., Goulding C., Beets P., Designing systems to monitor carbon stocks in forests and shrublands, For. Ecol. Manage. 164 (2002) 89-108.

[8] Davis M., Condron L., Impact of grassland afforestation on soil carbon in New Zealand: a review of paired-sites studies, Aust. J. Soil Res. 40 (2002) 675-690.

[9] Davis M.R., Allen R.B., Clinton P.W., Carbon storage along a stand development sequence in a New Zealand Nothofagus forest, For. Ecol. Manage. 177 (2002) 313-321.

[10] Ekanayake J.C., Marden M., Watson A.J., Rowan D., Tree roots and slope stability: a comparison between Pinus radiata and kānuka, N.Z. J. For. Sci. 27 (1997) 205-215.

[11] Eyles G.O., The New Zealand Land Resource Inventory erosion classification, Water Soil Misc. Publ. 85, 1985, 61 p.

[12] Gifford R.G., Plant respiration in productivity models: conceptualisation, representation and issues for global terrestrial carbon-cycle research, Funct. Plant Biol. 30 (2003) 171-186.

[13] Hall G.M.J., Mitigating an organisation's future net carbon emissions by native forest restoration, Ecol. Appl. 11 (2001) 1622-1633.

[14] Hall G.M.J., Hollinger D.Y., Simulating New Zealand forest dynamics with a generalised temperate forest gap model, Ecol. Appl. 10 (2000) 115-130.

[15] Harcombe P., Allen R.B., Wardle J.A., Platt K.H., Spatial and temporal patterns in structure, biomass, growth, and mortality in a monospecific Nothofagus solandri var. cliffortioides forest in New Zealand, J. Sustain. For. 6 (1998) 313-345.

[16] Hart P.B.S., Clinton P.W., Allen R.B., Nordmeyer A.H., Evans G., Biomass and macro-nutrients (above- and below-ground) in a New Zealand beech (Nothofagus) forest ecosystem: implications for carbon storage and sustainable forest management, For. Ecol. Manage. 174 (2003) 281-294.

[17] Hasselmann K., Climate change after Kyoto, Nature 390 (1997) $225-226$.

[18] Hinds H.V., Reid J.S., Forest trees and timbers of New Zealand, N.Z. For. Serv. Bull. 12 (1957) 1-221.

[19] IPCC, Land use change and forestry, in: Intergovernmental Panel for Climate Change, Revised 1996 Guidelines for National Greenhouse Gas Inventories: Reference Manual, Chapter 5, 1996, pp. 5.6-5.75.

[20] Jackson R.B., Banner J.L., Tobago E.G., Pockman W.T., Wall D.H., Ecosystem carbon loss with woody plant invasion of grasslands, Nature 418 (2002) 623-626.

[21] Jessen M.R., Crippen T.F., Page M.J., Rijkse W.C., Harmsworth G.R., McLoed M., Land use capability classification of the Gisborne-East Coast region, Landcare Research Science Series 21, Manaaki Whenua Press, 1999.

[22] Leuning R., A critical appraisal of a combined stomatal-photosynthesis model for $\mathrm{C}_{3}$ plants, Plant Cell Environ. 18 (1995) 339-357.

[23] Leuning R., Kelliher F.M., de Pury D.G.G., Schulze E.-D., Leaf nitrogen, photosynthesis, conductance and transpiration: scaling from leaves to canopies, Plant Cell Environ. 18 (1995) 1183-2000.

[24] LCDB, The New Zealand Landcover Database, Version 1. New Zealand Ministry for the Environment, Wellington, New Zealand, 2000, http://www.mfe.govt.nz/issues/land/land-cover-dbase, 14/11/2003.

[25] MacLaren J.P., Plantation forestry: it's role as a carbon sink, in: Bouma W.J., Pearman G.I., Manning M.R. (Eds.), Greenhouse: 
Coping with Climate Change, CSIRO Publishing, Collingwood, Victoria, Australia, 2000, pp. 417-436.

[26] Madgwick H.A.I., Jackson D.S., Knight P.J., Above ground dry matter, energy and nutrient contents of tree in an age series of Pinus radiata plantations, N.Z. J. For. Sci. 7 (1977) 445-468.

[27] MAF, Farm Monitoring Unit, Ministry of Agriculture and Forestry, Wellington, New Zealand, 2003.

[28] Marden M., Rowan D., Protective value of vegetation on tertiary terrain before and during Cyclone Bola, East Coast, North Island, New Zealand, N.Z. For. Sci. 23 (1993) 255-263.

[29] MfE, Climate Change: The New Zealand Response. II. New Zealand's Second National Communication under the Convention for Climate Change, New Zealand Ministry for the Environment, Wellington, New Zealand, 1997.

[30] MfE, Climate Change, More Than Just Carbon Dioxide: Significance, Sources, and Solutions for Non- $\mathrm{CO}_{2}$ Greenhouse Gases in New Zealand, New Zealand Ministry for the Environment, Wellington, New Zealand, 1998.

[31] MfE, National Inventory Report, New Zealand Greenhouse Gas Inventory, 1999-2001, New Zealand Climate Change Office, Ministry for the Environment, Wellington, New Zealand, 2003.

[32] Newsome P.F.J., The Vegetative Cover Map of New Zealand, Water and Soil Misc. Publ. No. 112, National Water and Soil Conservation Authority, Wellington, New Zealand, 1987.

[33] NZCCP, Climate Change. The Government's Preferred Policy Package. New Zealand Climate Change Project, Department of Prime Minister and Cabinet, PO Box 55, Wellington, 2001.

[34] NZCCP, National Inventory Report. New Zealand. Greenhouse Gas Inventory 1990-2000, New Zealand Climate Change Project, Department of Prime Minister and Cabinet, PO Box 55, Wellington, 2002.

[35] Page M.J., Trustrum N.A., Dymond J.R., Sediment budget to assess the geomorphic effect of a cyclonic storm, New Zealand, Geomorph. 9 (1994) 169-188.

[36] Paul K.I., Polglase P.J., Nyakuengama J.G., Khanna P.K., Change in soil carbon following afforestation, For. Ecol. Manage. 168 (2002) 241-257.

[37] Ramsey D., Spencer N., Caley P., Efford M., Hansen K., Lam M., Cooper D., The effects of reducing population density on contact rates between brushtail possums: implications for transmission of bovine tuberculosis, J. Appl. Ecol. 39 (2002) 806-818.

[38] Rahmstorf S., Ganopolski A., Long term global warming scenarios computed with an efficient coupled climate model, Climate Change 43 (1999) 353-367.
[39] Scott N.A., Tate K.R., Ford-Robertson J., Giltrap D.J., Smith C.T., Soil carbon storage in plantation forests and pastures: land-use change implications, Tellus 51B (1999) 326-335.

[40] Scott N.A., White J.D., Townsend J., Whitehead D., Leathwick J., Hall. G., Marden M., Rogers, G., Watson A.J., Whaley, P., Carbon and nitrogen distribution and accumulation in a New Zealand scrubland ecosystem, Can. J. For. Res. 30 (2000) 1246-1255.

[41] Scott N.A., Tate K.R., Giltrap D.J., Smith C.T., Wilde R.H., Newsome P.F., Davis M.R., Monitoring land-use change effects on soil carbon in New Zealand: quantifying baseline soil carbon stocks, Environ. Pollut. 116 (2002) S167-S186.

[42] Tate K.R., Scott N.A., Parshotam A., Brown L., Wilde R.H., Giltrap D.J., Trustrum N.A., Gomez B., Ross D.J., A multi-scale analysis of a terrestrial carbon budget: is New Zealand a source or sink of carbon? Agric., Ecol. Environ. 82 (2000) 229-246.

[43] Tate K.R., Scott N.A., Saggar S., Giltrap D.J., Baisden W.T., Newsome P.F., Trotter C.M., Wilde R.H., Land-use change alters New Zealand's terrestrial carbon budget: uncertainties associated with estimates of soil carbon change between 1990-2000, Tellus 55B (2003) 365-377.

[44] Tate K.R., Wilde R.H., Gitrap D.J., Baisden W.T., Saggar S., Trustrum N.A., Scott N.A., Soil carbon changes and uncertainties with New Zealand land-use change, Proceedings of the Supersoils 2004 Conference, Sydney, Australia, 2005 (in press).

[45] Trotter C.M., Tate K.R., Saggar S., Scott N.A., Sutherland M.A., A multi-scale analysis of a national terrestrial carbon budget and the effects of land use change, in: Shiyomi M., Kawahata H., Koizumi H., Tsuda A., Awaya Y. (Eds.), Global Environmental Change in the Ocean and on Land, Terrapub, Tokyo, 2003, pp. 311-342.

[46] Trustrum N.A., Gomez B., Page M.J., Reid L.M., Hicks D.M., Sediment production, storage, and output: the relative role of large magnitude events in steepland catchments, Z. Geomorph. (Suppl.) 115 (1999) 71-86.

[47] Trustrum N.A., Thomas V.J., Lambert M.G., Soil slip erosion as a constraint to hill country pasture production, Proc. N.Z. Grass. Assoc. 45 (1984) 66-76.

[48] UNFCCC, The Kyoto Protocol to the Convention on Climate Change, UN Climate Change Secretariat, Bonn, 1998.

[49] Wardle P., Vegetation of New Zealand, Cambridge University Press, Cambridge, UK, 1991.

[50] Whitehead D., Walcroft A.S., Scott N.A., Townsend J.A., Trotter C.M., Rogers G.N.D., Characteristics of photosynthesis and stomatal conductance in the shrubland species mannuka (Leptospermum scoparium) and kānuka (Kunzea ericoides) for the estimation of annual canopy carbon uptake, Tree Physiol. 24 (2004) 795-804. 